\title{
Why Are People Still Using Fixed Phones? The Case of Turk Telekom
}

\author{
S. Aksoy, D. Aydin-Unal, S. Akinci, and S. Verimli
}

\begin{abstract}
Telecommunication is among important drivers of globalization. It is a strategic investment which directly contributes to national economic performance bay way of accelerating information exchanges, improving efficiency and transparency. Introduction of faster and more sophisticated telecommunication services into the market affects customers' telecommunication service usage patterns. While subscriptions to traditional means (fixed-line services) decline slowly, adoption of more sophisticated means (wireless services, mobile-cellular phones) spreads remarkably faster. Concentrating on a small sample of fixed-phone subscribers to Turk Telekom, this research identifies three groups of motivations: perceived convenience, business purposes, and perceived advantage. Older customers find fixed-line services more convenient than younger customers, whereas other demographic characteristics such as gender, education, marital status, and duration of fixed-line ownership do not exhibit meaningful differences.
\end{abstract}

Index Terms - Customer motivations, fixed-line, fixed phone, landline, telecommunication, wireline.

\section{INTRODUCTION}

Technological developments, privatization in manufacturing and service sectors, liberalization of international trade, deregulation of public sector monopolies, changing consumer preferences have all contributed, directly or indirectly, to the evolution of the modern telecommunications industry. Today, new telecommunication services such as the third generation (3G) mobile telecommunication systems and Voice over Internet Protokol (VoIP) are gradually replacing more traditional services such as fixed-line and the second generation (2G) systems. According to International Telecommunication Union (ITU) estimations, mobile-cellular telephone subscriptions in 2013 in the world tripled to 6.8 billion just from 2.2 billion in 2005. Fixed telephone subscriptions, however, slightly declined to 1.1 billion from 1.2 over the same period. These shifts trigger several research questions in the telecommunication industry which are dealt with by researchers across the world [1]. The present study first looks briefly at the present literature on the fixed-line vs. mobile telecommunication services and then focuses on customer motivations to use fixed-line services in the Turkish market.

Manuscript received March 6, 2014, revised May 9, 2014.

Safak Aksoy, Duygu Aydın-Unal, and Serkan Akinci are with the Faculty of Economics and Administrative Sciences, Akdeniz University, Antalya, Turkey (e-mail: safak@akdeniz.edu.tr, duyguaydin@akdeniz.edu.tr, sakinci@akdeniz.edu.tr).

Sumeyye Verimli is with the Antalya Branch of Turk Telekom (e-mail: sumeyye.verimli@turktelekom.com.tr).

\section{MobiLe vs Fixed-Line: A Review OF Literature}

Starting at the end of the Twentieth Century, the world has become smaller as a result of a number of influential factors. Technological developments, increasing communication within and between societies, introduction of more sophisticated and economical means of transportation, and growing tourism activities have collectively eased the exchange of ideas, opinions, products, and cultural values between nations thus leading to an international integration called "globalization". Within this new phenomenon, technological developments and communication are of particular importance since they also activate other drivers. By shrinking time and distance, information and telecommunication technologies have made a positive impact on the efficiency of businesses and the quality of life of people. Telecommunication industry is considered to be a strategic investment that enhances national productivity by the way of reducing transaction costs, improving marketing information, and accelerating the diffusion of knowledge. The competitive advantage brought by this sector is pointed out to be the main reason for huge investments into the telecommunication industry in several nations [2]. This visible expansion in the sector, however, brought about a structural transformation that mobile communication services have grown at the expense of the fixed-line service usage. In the USA, 46.4 percent of households had fixed-line and cell phone services, 42.2 percent had fixed-line only service and 6 percent had cell-only service in 2004. Although the vast majority of households had a fixed-line at the time, it was underlined that cell-only households were becoming a more serious issue as estimates indicated that cell-only households would become even more prevalent in the future [3].

In Turkey, the number of fixed-line phone subscribers dropped steadily from 17.4 million to 13.9 million between 2008 and 2013. The same trend was also observed in the fixed-line penetration rate which declined from 24.5 percent to 18.4 percent over the same period. The situation is just the opposite for the cell phone adoption and usage. Mobile phone usage by Turkish people reached 169 billion minutes in 2012 from 75 billion minutes in 2008 [4].

Fixed and mobile service usage was also found to be correlated with customer demographics that the cell-only usage was greater in one-person households in the USA. Similarly, cell-only households constituted a much larger percentage of rented properties [3]. In the context of South East Asia, on the other hand, teenagers tended to use the cell phone for recreation and entertainment purposes, mainly playing games and listening to music, whereas they were less likely to use it for more sophisticated purposes such as 
petitioning, voting or shopping [5].

Despite the apparent shift exhibited by consumers from the wired to wireless telecommunication media, it is still worth investigating the former with a view to the relationship with the latter. A brief review of literature has demonstrated that those studies aiming for the fixed-line (also known as wireline or landline) telecommunication systems can be grouped under four different categories (Fig. 1).

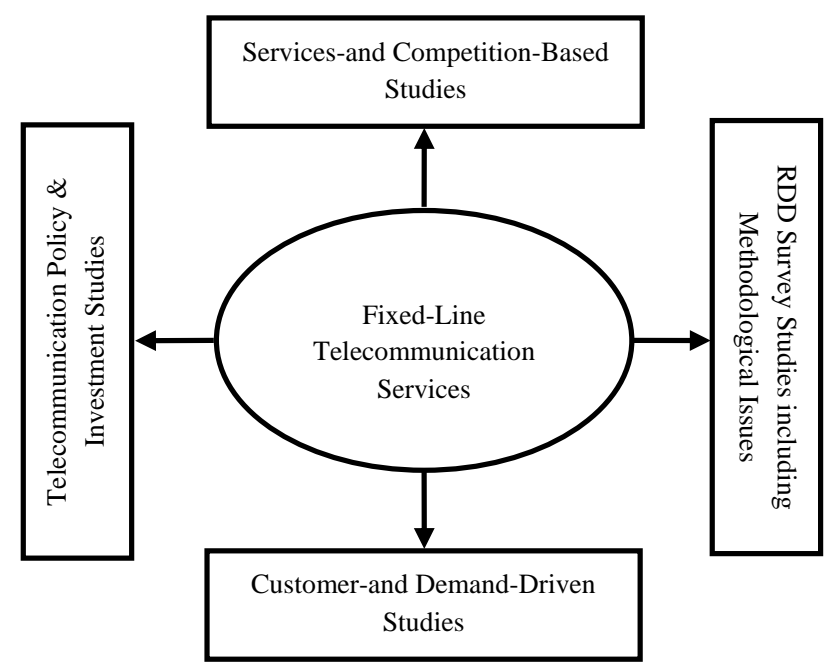

Fig. 1. Grouping of studies on fixed-line telecommunication services.

The first group, services- and competition-based studies, centers on service types and the question of substitutability between these services. Based on the empirical evidence collected in China, it is remarked that fixed and mobile subscriptions are fairly strong substitutes [6]. It is further added that fixed service having a strong technological infrastructure is an inferior good and that urbanization does not affect subscription. Thus, despite the existence of a tremendous growth in mobile services in China, the effect of the substitution between mobile and fixed-line has remained quite limited. In the Korean context, however, empirical evidence collected via a consumer preference survey has indicated that fixed-line and mobile call services do not belong to a single economic market, and thus their substitutability is questionable [7]. Nevertheless, it is also suggested that the two apparently separate markets may ultimately converge as call quality improves in wireless, albeit with a reasonable mobile price premium for portability. In addition to substitution and convergence issues between fixed-line and mobile networks, attention is drawn to the concept of complementarity, which relates to calls between fixed-line and mobile networks [8]. It is argued that in the earlier stages of mobile telecommunications the value of mobile subscription is heavily dependent on the ability to communicate with the dominant fixed-line network. As mobile penetration increases, however, this relative dependence on fixed-line is gradually decreased. The relationship between the two media is seen asymmetrical that fixed-line phones are substitutes in the mobile market, whereas mobile phones are not substitutes in the fixed-line market; thus substitutability and complementarity issues are re-emphasized [9].
The second group of studies is involved in coverage, sampling, and interviewing issues in random-digit dial (RDD) surveys for fixed-line phones. The main concern here is how to deal with the problem of non-coverage bias in such surveys. Various studies in this group handle the actual usage patterns for fixed-line and mobile phones, detection of these patterns in surveys, methodology development for the inclusion of mobile phone users into the RDD surveys, and adjusting the survey coverage for different ethnic groups in the society [3], [10], [11].

Investments in the telecommunication industry and related policy decisions constitute the third group of studies. Reference [2] informs us that wireline and wireless telecommunication investments do consistently drive subsequent usages, which in turn stimulate a nation's economic performance. Thus, encouragement of both investments in and usage of new telecommunication technologies are advised to policymakers. Re-emphasizing that modern telecommunications technology is an important driver in economic development, attention is also drawn to its institutional framework and the regulatory process both of which determine the sector's contribution to economic performance [12]. It is recommended that a transparent telecommunication policy should be asserted at the highest level of the national administration, and ownership/regulatory uncertainties among the system's actors should be cleared.

The forth group of studies are customer-based or demand-driven ones which handle the subject from the service recipients' viewpoint. Here, customer preferences and customer demographics are of central concern. In the USA, for example, low-income households reflect a quicker preference shift towards mobile phones while mobile phones are prominently becoming the preferred mode of voice communications regardless of income level [13]. In this, high installation costs for fixed-line phones across rural areas are pointed to be the main detriment for low-income households. Existence of a growing trend in the preference of only one form of communication thus will require service policy changes in directing subsidies for more efficiently. On the other hand, a decline has been spotted in the overall (i.e. whether fixed, mobile or other) telephone usage in the USA which is partly attributed to carriers' credit policies or secular changes in consumers' preferences for the use of telecommunication services [14]. In another empirical research among the fixed-line residential phone users in the UK, customers' satisfaction was found to be the strongest driver of customer retention. Furthermore, trust also had two separate effects on customer retention; a direct effect as well as a significant interaction effect together with satisfaction [15].

All the above literature basically stems from the changes in the telecommunications market which manifests itself with the number of subscriptions and usage rates for the fixed-line and mobile services over time. According to the statistical data publicized by International Telecommunication Union (ITU), the penetration rate (i.e. telephone subscription per 100 inhabitants) for fixed telephones in the world declined from 19.1 percent to 16.5 percent between 2005 and 2013. For mobile-cellular phones, however, a remarkable growth was observed from 33.9 percent to 96.2 percent in the same 
period [1]. To better understand this trend, the present research aims to probe consumers' fixed phone usage motivations together with possible relations with their demographic characteristics. As the majority of recent research targets mobile phone usage, this research rather taps the traditional medium of communication.

\section{Methodology}

\section{A. Research Objectives, Instrument, and Sampling}

The primary aim of this research is to investigate Turkish fixed phone subscribers' usage motivations and any possible impact of their demographic characteristics on their motivations. According to a recent research on fixed vs. mobile substitution in Turkey by Information and Communication Technologies Authority, 37 percent of Turkish households have fixed-line subscriptions, 33.4 percent have cancelled their subscription, and the remaining 29.6 percent have never had any fixed-line [4]. As is the case almost throughout Europe, the penetration rate in fixed telephones is approaching saturation [16]. Therefore, it is of critical importance to monitor shifting subscription patterns and introduce newer services in order to maintain the viability of the sector.

The present research was performed in cooperation with the main fixed-line telecommunication operator in Turkey, Turk Telekom (www.turktelekom.com.tr). The researchers conducted self-administered surveys with consumers in the offices of Turk Telekom in Antalya in January 2014.

The questionnaire was composed of four parts, the first and forth ones consisting of demographic information such as age, gender, income, and country of residence. The second part contained questions on customer motivations of fixed-line usage while the third part was allocated to business-specific questions which are not included into the analyses of this research. The questions directed to measure fixed-line usage motivation were determined after a focus group study. In the final form, 15 questions were included to measure motivation. All statements were measured by a seven-point Likert scale anchored by (1) "strongly disagree" to (7) "strongly agree".

The survey was performed in September and October 2013 between $09.00 \mathrm{am}$ and $06.00 \mathrm{pm}$. in predetermined random days. After explaining the aim of the research and taking their permission, the customers were given the self-administered questionnaire. Out of 259 customers who were asked to attend the study, 200 accepted to participate. At the end of the data collection period, 199 usable questionnaires were obtained.

\section{B. Research Findings}

The customers' demographic profiles showed that 65.8 percent of them were male, 36.7 percent were in the 36-55 age group, 68.3 percent married, and 74.4 percent had only one line at home. The complete profiles of the customers by selected demographic indicators were summarized in Table I.

The statements generated by the focus group to measure customer motivations in fixed-line usage were presented in descending order of means in Table II. The most important reason for using a fixed-line is internet usage. The following two reasons are the perceived convenience of fixed-line in emergency situations and the perception that fixed-line has superiority over mobile service with respect to health concerns.

TABLE I: DEMOGRAPHIC PROFILES OF THE RESPONDENTS

\begin{tabular}{|c|c|c|}
\hline Demographic Indicators & Category & Percent \\
\hline \multirow{2}{*}{ Gender } & Male & 65.8 \\
\hline & Female & 34.2 \\
\hline \multirow{5}{*}{ Age } & $20-29$ & 29.1 \\
\hline & $30-39$ & 36.7 \\
\hline & $40-49$ & 18.1 \\
\hline & $50-59$ & 11.1 \\
\hline & $>59$ & 5.0 \\
\hline \multirow{2}{*}{ Marital status } & Single & 31.7 \\
\hline & Married & 68.3 \\
\hline \multirow{5}{*}{ Education } & Primary School & 11.6 \\
\hline & High School & 37.7 \\
\hline & University & 38.2 \\
\hline & Master's & 11.1 \\
\hline & Ph.D. & 1.5 \\
\hline \multirow{6}{*}{ Duration of fixed-line ownership } & 1 year & 12.6 \\
\hline & 2 years & 13.6 \\
\hline & 3 years & 11.6 \\
\hline & 4 years & 6.5 \\
\hline & 5 years & 6.5 \\
\hline & $>5$ years & 49.2 \\
\hline \multirow{3}{*}{ Number of fixed-lines owned } & 1 line & 74.4 \\
\hline & 2 line & 17.6 \\
\hline & 3 or more & 8.0 \\
\hline
\end{tabular}

TABLE II: FIXED-LINE USAGE REASONS $(n=199)$

\begin{tabular}{lll}
\hline Items & Mean & S.D. \\
\hline To use internet & 5.025 & 2.43 \\
\hline It is more convenient in emergency situations & 4.372 & 2.48 \\
\hline $\begin{array}{l}\text { I believe that fixed-line is safer than mobile phones in } \\
\text { terms of human health }\end{array}$ & 4.357 & 2.39 \\
\hline My admiration of Turk Telekom as an institution & 4.266 & 2.22 \\
\hline It is free of charge between 07.00 am and 07.00 pm. & 4.231 & 2.48 \\
\hline I am accustomed to using fixed-line for a long time & 4.161 & 2.41 \\
\hline $\begin{array}{lll}\text { I see Turk Telekom as a public organization } \\
\text { Most of my friends own a fixed-line }\end{array}$ & 3.970 & 2.44 \\
\hline $\begin{array}{l}\text { I need a fixed-line in my office } \\
\text { To use the benefit of various campaigns for computers, } \\
\text { telephones, and devices (based on customer's }\end{array}$ & 3.849 & 2.38 \\
\hline $\begin{array}{l}\text { commitment) } \\
\text { To receive international calls without payment }\end{array}$ & 3.558 & 2.43 \\
\hline $\begin{array}{l}\text { To benefit from the subscribers-only campaigns of Turk } \\
\text { Telekom (housing insurance, wake-up service, }\end{array}$ & 3.256 & 2.32 \\
\hline \begin{tabular}{l} 
I do not like using mobile phones \\
\hline To use fax
\end{tabular} & 3.246 & 2.32 \\
\hline & 2.819 & 2.45 \\
\hline
\end{tabular}

To identify the underlying dimensions of customer motivations for fixed-line, the statements were subjected to factor analysis, generating three basic dimensions but eliminating five statements having factor scores less than 0.70. The first dimension relating to the perceived easiness and customer habits was named as "perceived convenience"; the second dimension was associated with business-related characteristics and thus was named as "business purposes"; and finally, the third one tapping the benefits of fixed-line was named as "perceived advantage" (Table III). 
TABLE III: VARIMAX ROTATED FACTOR ANALYSIS RESULTS

\begin{tabular}{|c|c|c|c|c|}
\hline Factor & $\begin{array}{c}\text { Cronbacl } \\
\text { Alfa }\end{array}$ & $\begin{array}{l}\text { hFactor } \\
\text { interpretation } \\
\text { (\% variance } \\
\text { exp.) }\end{array}$ & Loading & Usage Criteria \\
\hline \multirow{5}{*}{ F1 } & \multirow{5}{*}{.822} & \multirow{5}{*}{$\begin{array}{l}\text { Perceived } \\
\text { Convenience } \\
(36.74 \%)\end{array}$} & .795 & $\begin{array}{l}\text { I am accustomed to using } \\
\text { fixed-line for a long time }\end{array}$ \\
\hline & & & .758 & $\begin{array}{l}\text { I do not like using mobile } \\
\text { phones }\end{array}$ \\
\hline & & & .737 & $\begin{array}{l}\text { I believe that fixed-line is } \\
\text { safer than mobile phones in } \\
\text { terms of human health }\end{array}$ \\
\hline & & & .719 & $\begin{array}{l}\text { Most of my friends own a } \\
\text { fixed-line }\end{array}$ \\
\hline & & & .716 & $\begin{array}{l}\text { It is more convenient in } \\
\text { emergency situations }\end{array}$ \\
\hline \multirow{3}{*}{$\mathbf{F 2}$} & \multirow{3}{*}{.790} & \multirow{3}{*}{$\begin{array}{l}\text { Business } \\
\text { Purposes } \\
(18.22 \%)\end{array}$} & .865 & To use fax \\
\hline & & & .839 & $\begin{array}{l}\text { I need a fixed-line in my } \\
\text { office }\end{array}$ \\
\hline & & & .736 & To use the alarm system \\
\hline \multirow[b]{2}{*}{ F3 } & \multirow[b]{2}{*}{.413} & Perceived & .799 & To use internet \\
\hline & & $\begin{array}{l}\text { Advantage } \\
(10.25 \%)\end{array}$ & .748 & $\begin{array}{l}\text { It is free of charge between } \\
07.00 \text { am and } 07.00 \mathrm{pm} .\end{array}$ \\
\hline
\end{tabular}

Customers' responses were further probed to investigate whether customer demographics played a role on their motivations. The three motivational groups were compared in terms of each demographic indicator by way of ANOVA and t-tests.

In performing the tests, age groups were re-organized as young (20-29), mid-aged (30-49), and older $(50+)$ for a more concise format. ANOVA tests revealed meaningful differences between age categories only in the "perceived convenience" group (Table IV). So that Tukey test was employed to see the specificity (Table V).

TABLE IV: ANOVA TEST RESUlTS FOR AGE GROUPS N Mean S.D. S.E. 95\% Confidence Interval for Mean

Lower B. Upper B.

\begin{tabular}{lcccccc}
\hline $\begin{array}{l}\text { Young } \\
(\mathbf{2 0 - 2 9 )}\end{array}$ & 58 & 3.54 & 1.717 & .225 & 3.087 & 3.989 \\
\hline $\begin{array}{l}\text { Mid-Aged } \\
(\mathbf{3 0 - 4 9 )}\end{array}$ & 109 & 4.03 & 1.848 & .177 & 3.682 & 4.384 \\
$\begin{array}{l}\text { Older } \\
(\mathbf{5 0 +})\end{array}$ & 32 & 4.71 & 1.775 & .314 & 4.066 & 5.346 \\
\hline Total & 199 & 3.99 & 1.829 & .129 & 3.741 & 4.253 \\
\hline
\end{tabular}

\begin{tabular}{lcccc}
\multicolumn{4}{c}{ TABLE V: TUKEY TEST Results } \\
\hline $\begin{array}{l}\text { Age } \\
\text { groups }\end{array}$ & $\begin{array}{c}\text { Mean } \\
\text { Difference }\end{array}$ & S.E. & Sig. & 95\% Confidence \\
\cline { 3 - 4 } & & & Interval \\
\cline { 3 - 4 }
\end{tabular}

\begin{tabular}{|c|c|c|c|c|c|c|}
\hline \multirow{2}{*}{$\begin{array}{l}\text { Young } \\
(20-29)\end{array}$} & $\begin{array}{l}\text { Mid-aged } \\
(30-49)\end{array}$ & -.495 & .292 & .210 & -1.186 & .196 \\
\hline & $\begin{array}{l}\text { Old } \\
(50+)\end{array}$ & -1.168 & .396 & $.010^{*}$ & -2.104 & -.232 \\
\hline \multirow{2}{*}{$\begin{array}{l}\text { Mid-aged } \\
(30-49)\end{array}$} & $\begin{array}{l}\text { Young } \\
(20-29)\end{array}$ & .495 & .292 & .210 & -.196 & 1.186 \\
\hline & $\begin{array}{l}\text { Old } \\
(50+)\end{array}$ & -.673 & .362 & .153 & -1.528 & .181 \\
\hline \multirow{2}{*}{$\begin{array}{l}\text { Older } \\
(50+)\end{array}$} & $\begin{array}{l}\text { Young } \\
(20-29)\end{array}$ & 1.168 & .396 & $.010^{*}$ & .233 & 2.104 \\
\hline & $\begin{array}{l}\text { Mid-aged } \\
(30-49)\end{array}$ & .673 & .362 & .153 & -.181 & 1.528 \\
\hline
\end{tabular}

As presented in detail in Table $\mathrm{V}$, there is a clear distinction between younger and older age groups with respect to the perceived convenience of fixed-line services. Older customers find fixed-line services more convenient than younger customers which can be attributed to their relatively disadvantageous position towards newer, non-traditional, and more sophisticated mobile technologies (Fig. 2). Except age, no other demographic characteristics displayed any meaningful difference.

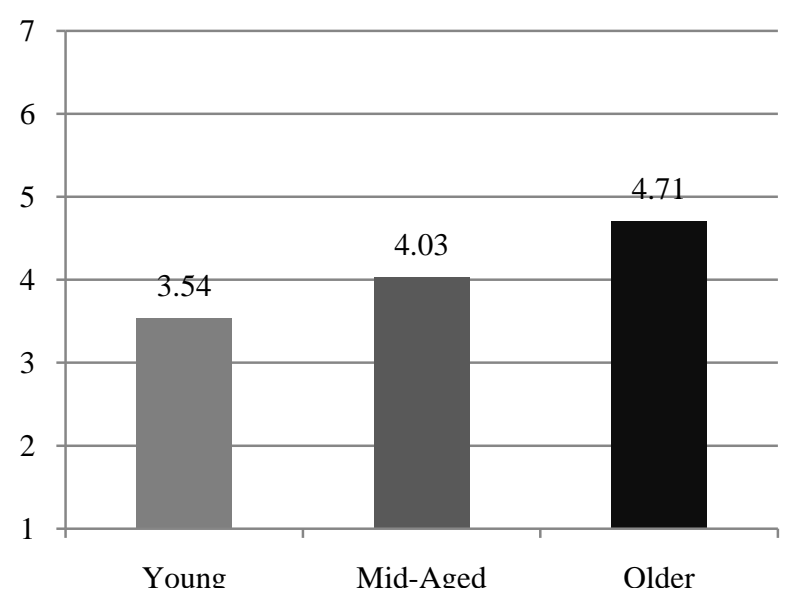

Fig. 2. Mean values of age groups according to "perceived convenience".

\section{CONCLUSION AND Discussion}

The fast evolving telecommunication technology and the willingness to adopt them by the society have stimulated the actors of telecommunication industry to offer a wide range of new services while retaining the traditional means. It is therefore becoming more critical for the industry players to understand how the new services are different from traditional telecommunication services and what consumers think about the traditional vs more advanced telecommunication solutions. As noted in [17], the existing literature is short of comparative studies examining traditional and contemporary telecommunication services from a competitive market perspective. This gives rise to several questions such as "Can one type of telecommunications service meet the entire needs of customers?", "What is the degree of substitutability between the traditional and advanced means of telecommunication?", "Are the two types of services complementary to each other?" and so on. In fact, the scope of research in this area is much wider when other issues such as telecommunication policies and investments, market surveys, customer behavior, and demographics etc. are included. Thus the resent study very briefly highlights prominent research clusters in the extant literature and then investigates fixed-line phone usage motivations of customers with a view to their demographic characteristics.

Four main clusters of research identified in the present study are: Telecommunication Policy and Investment Studies, Services/Competition Based Studies (including substitutability and complementarity between various services), RDD Survey Studies (also covering methodological issues), and Customer-and Demand- Driven 


\section{Studies.}

Relying on a convenient sample drawn from the existing customers of Turk Telekom, this research aimed to understand fundamental motivations of fixed-line telecommunication service users. Research results pointed out to the existence of three motivational usage dimensions: Perceived Convenience, Business Purposes, and Perceived Advantage. Those customers in the "Perceived Advantage" group displayed differences across age categories. Thinking of fixed-line services to be a safer solution for human health and sticking to their long-lasting habits, mature customers were significantly discriminated against the 20-29 age group. This is quite logical that older age groups are likely to be slower in changing their habits, whereas young generations are expected to be more skilled in learning and adoption new technologies. Although there are several studies investigating young people's use of mobile telecommunication technologies [5], [10], [18], there is a paucity of research in their conception of more traditional means. We suggest deeper research in understanding consumers' view of more traditional telecommunication services.

\section{ACKNOWLEDGMENT}

The authors would like to thank Mr. Volkan SEN, Area Retail Sales Manager of Turk Telekom, for his valuable support in conducting this research.

\section{REFERENCES}

[1] ITU. (2013). International Telecommunication Union (database), International Telecommunication Union. [Online]. Available: http://www.itu.int/en/ITU-D/Statistics/Pages/stat/ default.aspx

[2] S. C. Yang and L. Olfman, "The effects of international telecommunication investment: Wireline and wireless technologies, 1993-1998," Telecommunications Policy, vol. 30, no. 5-6, pp. 278-296, 2006.

[3] C. Tucker, J. M. Brick, and B. Meekins, "Household telephone service and usage patterns in the United States in 2004: implications for telephone samples," Public Opinion Quarterly, vol. 71, no. 1, pp. 3-22, 2007.

[4] Bilgi Teknolojileri ve İletişim Kurumu, "Üç aylık pazar verileri raporu," Ankara, 2013.

[5] W. Y. Lin, X. Zhang, J. Y. Jung, and Y. C. Kim, "From the wired to wireless generation? Investigating teens' Internet use through the mobile phone," Telecommunications Policy, vol. 37, no. 8, pp. 651-661, 2013.

[6] M. R. Ward and S. Zheng, "Mobile and fixed substitution for telephone service in China," Telecommunications Policy, vol. 36, no. 4, pp. 301-310, 2012.

[7] H. Rhee and M. Park, "Fixed-to-mobile call substitution and telephony market definition in Korea," Journal of Regulatory Economics, vol. 40, no. 2, pp. 198-218, 2011.

[8] R. Albon, "Fixed-to-mobile substitution, complementarity and convergence," Agenda, vol. 13, no. 4, pp. 309-322, 2006.

[9] C. Garbacz and H. G. Thompson, "Demand for telecommunication services in developing countries," Telecommunications Policy, vol. 31, no. 5 , pp. 276-289, 2007.

[10] D. Currivan, D. Roe, and J. Stockdale, "The impact of landline and cell phone usage patterns among young adults on RDD survey outcomes," American Association for Public Opinion Research Annual Meetings, in New Orleans, May 16, 2008.

[11] S. Lee, M. Elkasabi, and L. Streja, "Increasing cell phone usage among Hispanics: implications for telephone surveys," American Journal of Public Health, vol. 102, no. 6, pp. 19-24, 2012.
[12] J. B. Burnham, "Telecommunications policy in Turkey: Dismantling barriers to growth," Telecommunications Policy, vol. 31, no. 3, pp. 197-208, 2007

[13] J. A. Hauge, E. P. Chiang, and M. A. Jamison, "Whose call is it? Targeting universal service programs to low-income households' telecommunications preferences," Telecommunications Policy, vol. 33, no. 3, pp. 129-145, 2009

[14] P. R. Zimmerman, "Recent developments in US wireline telecommunications," Telecommunications Policy, vol. 31, no. 6, pp. 419-437, 2007

[15] C. Ranaweera and J. Prabhu, "The influence of satisfaction, trust and switching barriers on customer retention in a continuous purchasing setting," International Journal of Service Industry Management, vol. 14, no. 4, pp. 374-395, 2003.

[16] Bilgi Teknolojileri ve İletişim Kurumu (BTK), "Sabit telekomünikasyon hizmetleri piyasasında rekabet durumu analizi ve öneriler," Ankara, 2012

[17] Y. C. Lee, "Competitive relationships between traditional and contemporary telecommunication services in Taiwan," Telecommunication Policy, vol. 35, no. 6, pp. 543-554, 2011.

[18] R. Ling, " 'We will be reached': the use of mobile telephony among Norwegian youth," Information Technology and People, vol. 13, no. 2, pp. 102-120, 2000

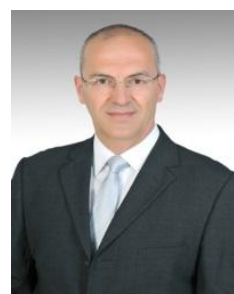

S. Aksoy was born in Istanbul. He graduated from Ankara University in 1982. He obtained his Ph.D in international marketing from the University of Bath, England, in 1992. He became a full-professor in 2004 and is currently affiliated with the Department of Business Administration, Faculty of Economics and Administrative Sciences, Akdeniz University, Antalya, Turkey. His international publications appear in Journal of Business Research, International Marketing Review, European Journal of Marketing, Journal of Air Transport Management, International Journal of Bank Marketing, Managing Service Quality, and Marketing Intelligence \& Planning.

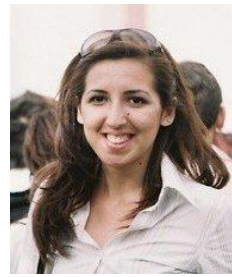

D. Aydin-Unal was born in Antalya on March 6, 1984. She graduated from Anadolu University. She is a research assistant and a Ph.D student in the Department of Business Administration, Faculty of Economics and Administrative Sciences, Akdeniz University. Currently, she is writing a dissertation about consumption culture in Turkey and discourse.

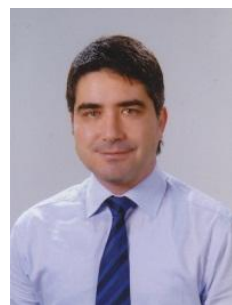

S. Akinci is an associate professor of marketing at Akdeniz University, Antalya. He received his Ph.D. from Akdeniz University. His research interests include electronic commerce, bank marketing, service quality, and customer satisfaction. He has published articles in the Journal of Business Research, European Journal of Marketing, Journal of Air Transport Management, International Journal of Bank Marketing, Managing Service Quality, and Marketing Intelligence \& Planning, as well as in various conference proceedings.

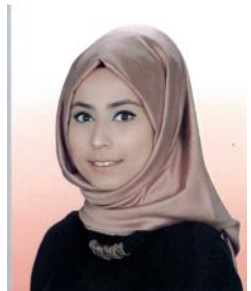

S. Verimli was born in Antalya on September 28 1989. She graduated from Istanbul University, Faculty of Business in 2011. She received English language training from the Department of Foreign Languages, Galatasaray University, Turkey. Currently, she is a MBA student in the Department of Business Administration in Akdeniz University. She has been employed by Turk Telekom, Individual Customer Services Department. 